\title{
Infection characteristics of a trematode in an estuarine isopod: influence of substratum
}

\author{
Susana M. Ferreira ${ }^{1, *}$, K. Thomas Jensen ${ }^{2} \&$ Miguel A. Pardal ${ }^{1}$ \\ ${ }^{1}$ Department of Zoology, IMAR - Institute of Marine Research, University of Coimbra, 3004-517 Coimbra, Portugal \\ ${ }^{2}$ Department of Marine Ecology, Institute of Biological Sciences, University of Aarhus, Finlandsgade 14, DK-8200 \\ Aarhus N, Denmark \\ (*Author for correspondence: Tel.: + 351239836386,fax: +351239823603,E-mail: smff@ci.uc.pt)
}

Received 25 July 2004; in revised form 9 September 2004; accepted 28 September 2004

Key words: parasitism, Maritrema, Cyathura, Hydrobia, sediment

\begin{abstract}
The estuarine isopod Cyathura carinata is a second intermediate host to microphallid trematodes, which use mud snails Hydrobia spp. and shorebirds as respectively first intermediate and final hosts. To identify processes responsible for infection patterns observed in $C$. carinata, a short-term microcosm experiment was conducted with both macroinvertebrates and one of their common parasites - Maritrema subdolum. Fine sand collected from two different shallow water sites was used to test if sediment type could affect infection rates. After 7 days at $25^{\circ} \mathrm{C}$, C. carinata from the substratum with the highest proportion of particles $<125 \mu \mathrm{m}$ were more surface active and obtained significantly more $M$. subdolum individuals than isopods from the other sediment type. No parasite-induced effects on the hosts were found during this short-term experiment. The distribution pattern of microphallid cysts and mesocercariae inside the isopods revealed that $M$. subdolum cercariae primarily penetrated through the pleopods and afterwards located themselves in the middle-posterior region of the host's body. Even if it was not possible to identify the factor responsible for the observed infection patterns (cercariae production and/or host behaviour), the results of this experiment indicate that small-scale factors, such as differences in substratum and associated features, may have considerable impact on infections of host populations.
\end{abstract}

\section{Introduction}

In marine shallow water ecosystems, many invertebrates are hosts to a rich and diverse trematode fauna. In particular, prosobranch snails and either crustaceans or bivalves are used as first and second intermediate hosts by digenean trematodes (Lauckner, 1980, 1983; Meyers, 1990). These parasites are widespread in estuaries and coastal lagoons where their final hosts (water birds) congregate. It is known that parasites may have an impact on physiology (Meissner \& Bick, 1999) and behaviour (Thomas et al., 1998; McCarthy et al., 2000; Combes, 2001) of their host specimens. However, population consequences have not yet been sufficiently explored. Recent evidence suggests that trematodes may determine the dynamics of their invertebrate host populations, with long-lasting community consequences (Jensen \& Mouritsen, 1992; Meissner \& Bick, 1997; Mouritsen \& Jensen, 1997; Mouritsen et al., 1997, 1998; Meissner, 2001). Some digenean are known to promote trophic transmission by manipulating their intermediate hosts' behaviour (Lafferty \& Morris, 1995; Thomas et al., 1998; Combes, 2001). So, considering digeneans potential to affect invertebrate populations, identification of ecological factors that influence spatio-temporal dynamics of parasites is an important issue.

High prevalence and intensity patterns of microphallid trematodes were observed in the isopod 
Cyathura carinata from the Mondego Estuary, western coast of Portugal (Jensen et al., 2004). The trematode Maritrema subdolum is frequent within the isopod and also within its first intermediate host, the mud snail Hydrobia ulvae (Jensen et al., 2004). So far, trematodes have only been reported from C. carinata a few times (Reimer, 1963; Schulenburg \& Wägele, 1998; Schulenburg et al., 1999; Jensen et al., 2004). Therefore, studies examining host effects or factors influencing infection characteristics are needed. Spatial patterns of parasites in C. carinata (Jensen et al., 2004) could be related to changes in sediment composition. So, cercariae production may depend on the availability of food resources for the snail host, such as bacteria and microalgae. The behaviour of the second intermediate host may also vary with sediment properties and thus their exposure to cercariae. To study both $M$. subdolum infection patterns and parasite effects on C. carinata, a smallscale short-term experiment was established with substrata from two different shallow water sites. Behaviour, survival rate, infection characteristics and parasite distribution within the hosts' body were the response variables analysed.

\section{Materials and methods}

\section{Specimens' collection and storage}

H. ulvae snails were collected at the Mondego Estuary. In laboratory, these gastropods were checked individually for cercariae shedding in small petri dishes, at 20 psu and $24{ }^{\circ} \mathrm{C}$, under constant light conditions. Cercariae were identified to species level, according to Deblock (1980). Infected $H$. ulvae were sorted and kept separately in small aquaria at $15^{\circ} \mathrm{C}$.

C. carinata individuals were also collected in the same estuary, at a site where the population is abundant and almost non-parasitised. Collected specimens were kept in laboratory at 20 psu and $15{ }^{\circ} \mathrm{C}$.

\section{Sediment collection and treatment}

Sediment was collected from two Danish estuaries (Haurvig, Ringkøbing Fjord and Aggersund, Limfjord). The two substrata differed visually in colour: one was brown whilst the other was light yellow. Sediment was sieved through a $0.5 \mathrm{~mm}$ mesh to remove macrofaunal individuals. At the end of the experiment, organic matter content and granulometric properties were determined (Holme \& McIntyre, 1984). Unfortunately, most of the organic matter was washed away during the sieving process. The two substrata had similar median grain size $(\approx 210 \mu \mathrm{m})$. However, one substratum contained a lower proportion of the grain size fraction $<125 \mu \mathrm{m}$ than the other $(9.4 \%$ within the brown substratum vs. $18 \%$ within the yellow one).

\section{Experimental design}

Twenty plastic containers were used as experimental aquaria. Each one had a $4 \mathrm{~cm}$ layer of sediment and 11 of brackish water $(\approx 22 \mathrm{psu})$. Brown substratum was used in half of the containers and yellow substratum in the other half. The aquaria were kept in a $25{ }^{\circ} \mathrm{C}$ room with a $12 \mathrm{~h}$ light/darkness cycle. A lid to diminish evaporation covered all containers. To prevent oxygen depletion, air was supplied through a glass pipette, 15 min each $4 \mathrm{~h}$ of light and each $2 \mathrm{~h}$ of darkness. The aquaria were placed randomly to avoid gradient effects. Experimental animals were introduced $24 \mathrm{~h}$ after the system was established. They were carefully selected to secure identical sizes in each container.

Five $H$. ulvae snails were introduced in each aquarium. They were enclosed in a net cylinder (1 $\mathrm{mm}$ gauged mesh, $35 \mathrm{~mm}$ in diameter), placed in the center of every container, to prevent their escape from the sediment-water system. Each sediment treatment consisted of five aquaria containing $M$. subdolum infected $H$. ulvae (treatments) and five other with Cryptocotyle infected snails (controls). Cryptocotyle do not use C. carinata as their second intermediate host, but encyst on fish instead. This was preferable rather than using noninfected $H$. ulvae because it is difficult to prove a non-infected state of living snails (Curtis \& Hubbard, 1990). Afterwards, 16 C. carinata were added to each aquarium, corresponding to a density of 1304 ind $\mathrm{m}^{-2}$, equivalent to the natural conditions when the experiment was performed (Pardal et al., 2002; Ferreira et al., 2004). The isopods could freely pass through the net container enclosing the snails. 
The experiment ran for 7 days. Temperature, salinity and animal activity were daily checked. The number of isopods swimming, crawling on the surface or extruding the burrow were registered every morning, as well as the presence of tracks on the sediment of all aquaria. At the end, H. ulvae were removed from the containers, and each group was kept isolated in Petri dishes and stored at $15{ }^{\circ} \mathrm{C}$. The aquaria were emptied and live C. carinata were counted. Afterwards, they were placed at $6{ }^{\circ} \mathrm{C}$ until dissection. All specimens were sexed, measured and inspected under a stereomicroscope for the presence, number and location of parasites. $M$. subdolum were found inside $C$. carinata, both as mesocercariae (tailless cercariae, moving in the host's tissues) and as recently formed metacercariae (encysted form of the parasite).

\section{Cercarial emergence}

To estimate cercariae shedding rates, $H$. ulvae snails were incubated again in the $25^{\circ} \mathrm{C}$ room, after having recovered for one week at $15{ }^{\circ} \mathrm{C}$. After $48 \mathrm{~h}$ under the same environmental conditions as the ones used during the experiment, each group of snails was removed to a clean Petri dish containing only brackish water. After $1 \mathrm{~h}$, they were re-established in their original dish. The cercariae produced were stained with neutral lugol and counted under a stereomicroscope. The same procedure was repeated on the two following days.

\section{Data analysis}

Statistical analyses were performed using the MINITAB 10.2 software package. All data were inspected for violation of required assumptions and, if so, proper transformations or non-pararametric tests were used (Zar, 1996).

\section{Results}

\section{Infection rates and survival}

During the 7 days experimental period, significantly more $C$. carinata specimens from the yellow than from the brown substratum became infected with $M$. subdolum (yellow substratum: $67.1 \pm 7.5 \%$ vs. brown substratum: $22.2 \pm 5.1 \%$, mean \pm SE; $t$-test: $\left.t_{8}=-4.95, p<0.01\right)$ (Fig. 1a). No infections were observed in isopods from containers with Cryptocotyle infected snails. $M$. subdolum was also significantly more abundant within infected C. carinata from the yellow substratum (yellow substratum: $31.0 \pm 4.6$ parasites vs. brown substratum: $7.2 \pm 2.9$ parasites; mean \pm SE; $t$-test: $\left.t_{8}=-4.41, p<0.01\right)$ (Fig. 1b). A maximum of 12 trematode larvae were found in a single individual.

Pooling together the $3 \mathrm{~h}$ of $H$. ulvae postexperimental shedding, snails from the brown substratum produced 438 cercariae (median), varying from 267 to 896 , whereas those from the yellow substratum produced 1086 cercariae (median), varying from 186 to 2013. This difference was not significant (Mann-Whitney $U=6, p>0.05$ ). Neither was there a significant correlation between the infections obtained and the number of cercariae produced in each aquarium (Spearman's rho $=0.333, p>0.05, n=10$ ).

C. carinata survival rates were higher on the brown substratum $(98.8 \pm 1.3 \%$ for control and
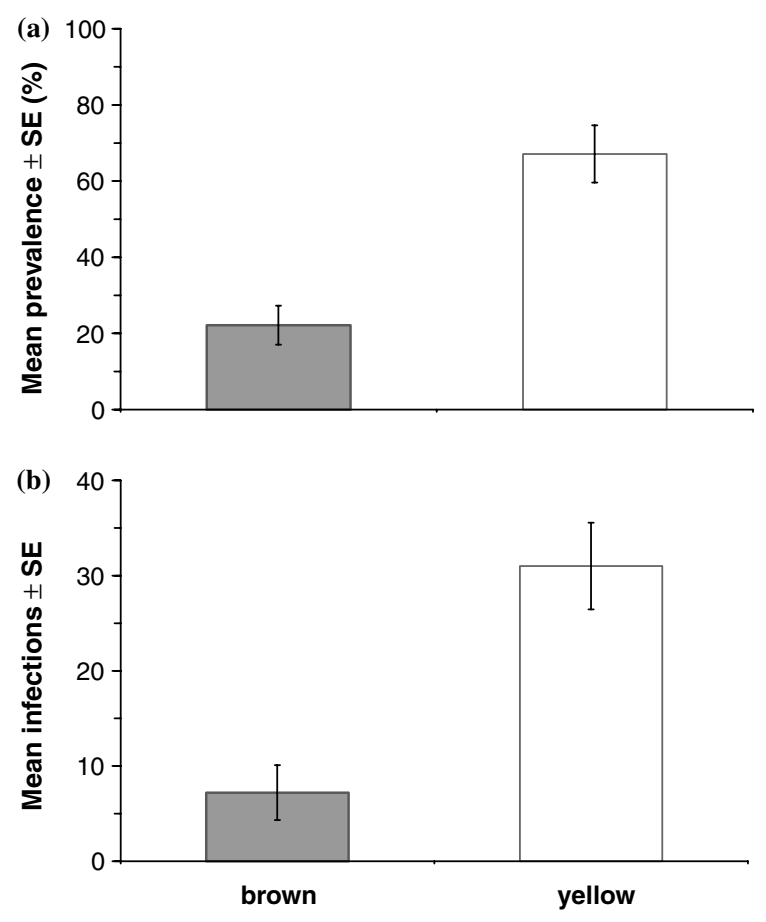

Figure 1. (a) Prevalence of M. subdolum in C. carinata and (b) intensity (mean $\pm \mathrm{SE}$ ) of the total number of infections found in each replicate of the brown and yellow substrata aquaria. 


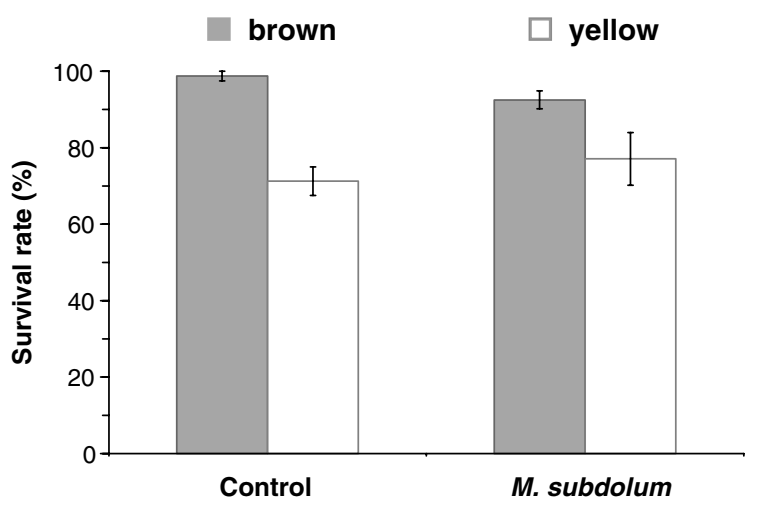

Figure 2. Survival rate (mean $\pm \mathrm{SE}$ ) of $C$. carinata as a function of substratum and parasite treatment (control: isopods incubated with Cryptocotyle infected snails).

$92.5 \pm 2.3 \%$ for $M$. subdolum treatment; mean $\pm \mathrm{SE})$ than on the yellow one $(71.3 \pm 3.8 \%$ for control and $77.2 \pm 6.9 \%$ for $M$. subdolum treatment; mean \pm SE) (Fig. 2). A two-way ANOVA revealed a significant effect of substratum type $\left(F_{1,16}=26.98, p<0.001\right)$, but there were no parasite effects $\left(F_{1,16}=0.00, p>0.05\right)$ nor any interaction between the two factors $\left(F_{1,16}=2.17\right.$, $p>0.05)$. No correlations were established between survival rates and the numbers of infections acquired by all $C$. carinata within $M$. subdolum treatment aquaria $\left(r_{3}=-0.268, p>0.05\right.$ for the brown substratum and $r_{3}=-0.447, p>0.05$ for the yellow one).

\section{Parasite location within C. carinata}

Most mesocercariae were found in the posterior body segments (Fig. 3). The pleon accommodated $70 \%$ of the mesocercariae and $44 \%$ of all cysts. The head region did also contain a considerable fraction of mesocercariae $(8.6 \%)$. Still, most metacercariae were found scattered along the body cavity of the pereon (52\% in the total). Although dead $C$. carinata individuals were removed and examined daily, no trematodes were found within them. The rapid decomposition of dead isopods can destroy the mesocercarie present in the host tissues. This could have underestimated the total numbers of infections obtained. In the yellow substratum, numerous nematodes where found inside the remaining exoskeletons of dead
C. carinata. They may also have contributed to the absence of mesocercariae in dead isopods.

\section{Host behaviour}

In the beginning, it was possible to observe a higher activity of isopods from the yellow substratum containers (Fig. 4a). However, it declined with time, ceasing after the fifth day. At the same time, sediment tracks appeared from the fourth day onwards, mainly within the brown substratum aquaria (Fig. 4b). Tracks were made during darkness, being perfectly visible in the morning and fading throughout the day, showing that C. carinata was more surface active at night.

A one-way ANOVA was performed to test if the intensity of microphallid larvae differed between males, ovigerous and non-reproductive females (respectively, $2.1 \pm 0.5,3.2 \pm 1.0$ and $3.4 \pm 0.4$ parasites, mean $\pm \mathrm{SE}$ ). However, there were no significant differences between them $\left(F_{2,50}=0.95, p>0.05\right)$, neither between the frequency of infected and non-infected specimens (8 males, 5 ovigerous and 47 non-reproductive females infected with $M$. subdolum vs. 6, 9 and 66 non-infected individuals, respectively; $\chi^{2}$-test: $\left.\chi_{2}^{2}=0.222, p>0.05\right)$. Also, no relation between $C$. carinata's cephalic length and infection intensity was found $\left(r_{58}=0.079, p>0.05\right)$.
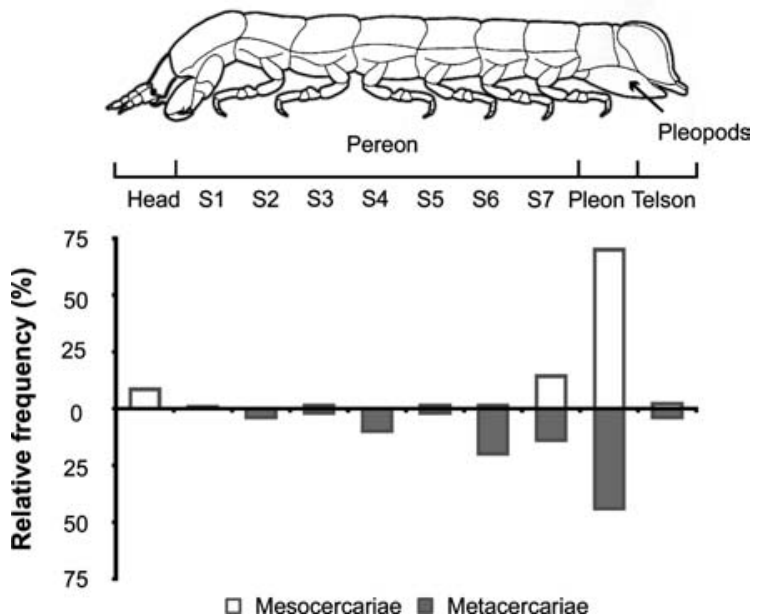

Figure 3. Distribution of meso $(n=140)$ and metacercariae $(n=50)$ of $M$. subdolum in different body parts of infected C. carinata $(n=60)$. S1-S7 are the seven segments of the pereon region of the isopod's body. 

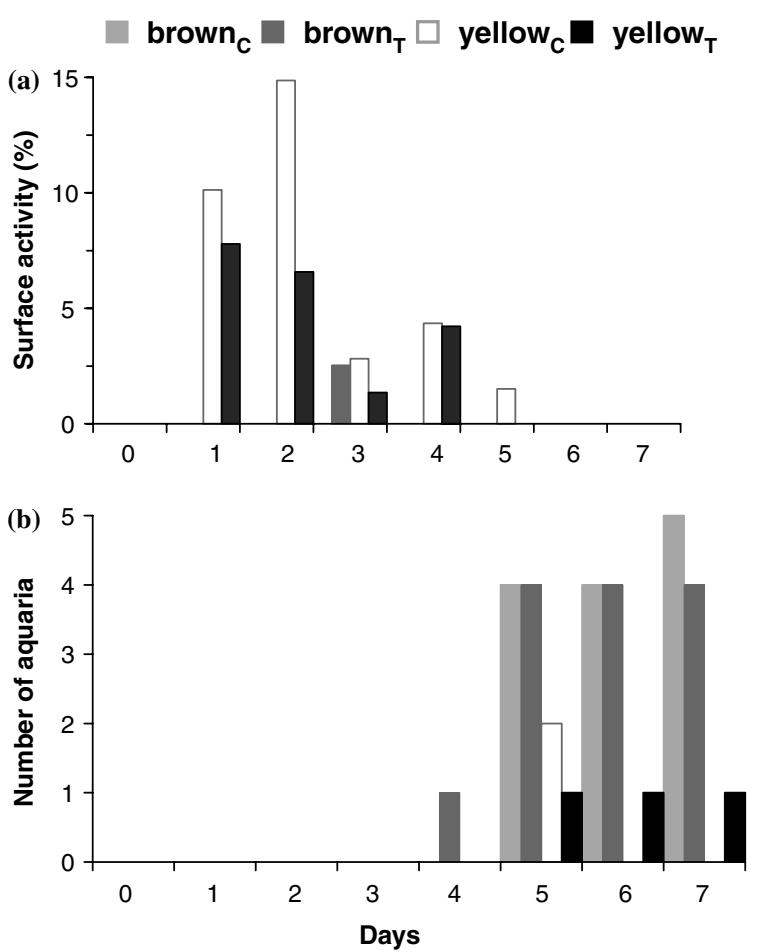

Figure 4. Surface activity of C. carinata in the brown and yellow substrata aquaria. (a) Relative frequency of isopods swimming, crawling on the surface or extruding the burrow, during light hours. (b) Number of aquaria with isopod tracks on the sediment's surface, made during darkness. (C, control; T, M. subdolum treatment).

\section{Discussion}

Prevalence and intensity of $M$. subdolum were higher within $C$. carinata from the yellow than from the brown substratum. Variation in either cercariae production and/or isopods' behaviour in relation to substratum type could be responsible for the observed pattern.

H. ulvae from the yellow substratum seemed to produce more cercariae than those from the brown type aquaria, promoting higher infection rates. The higher proportion of particles $<125 \mu \mathrm{m}$ from the yellow substratum could indicate the presence of more food for the snails, as they ingest the small grains and their associated microalgae. Nevertheless, data did not support an impact of sheddingrates on the numbers of infections acquired in C. carinata. Post-experimentally estimated shortterm rates may not necessarily reflect cercariae production during the experimental period (Curtis
\& Hubbard, 1990). They are normally subjected to considerable variation within and between snails (Théron \& Moné, 1984). Sediment contamination by heavy metals or other pollutants have been proved to affect the survivorship and/or transmission capacity of digenean cercariae (MacKenzie, 1999; Morley et al., 2003). Still, the sediment used in the experiment was collected from brackish water sites inhabited by dense and varied stocks of invertebrates. Furthermore, the sites are situated far away from any industrial plants that potentially could be sources for contaminants.

M. subdolum is frequently found in C. carinata from the Mondego estuary (Jensen et al., 2004), but this experiment revealed that it has a low transmission success. Based on the post-experimentally estimated shedding rates, it is plausible to assume that many thousands of cercariae were released in each aquarium. Nevertheless, only a maximum of 42 infections was found in one of the experimental $C$. carinata populations. Behavioural traits may contribute to this. M. subdolum cercariae swim in the bottom layer of the water column, (Mouritsen, 2002), what may be interpreted as an adaptive strategy to reach bottom-dwelling crustaceans (Meissner \& Bick, 1997; Mouritsen \& Jensen, 1997; Mouritsen et al., 1998; Mouritsen, 2001). C. carinata is a predator (Wägele, 1981; Ólafsson \& Persson, 1986) that spends most of the time hiding and waiting for a prey to pass above its burrow. As M. subdolum distribution within the C. carinata's body indicated that pleopods were the main infection path, cercariae have to be drawn inside the isopod's burrow, through very weak ventilation currents created by it (own observation). When caught on the pleopods, the cercariae crawl towards the host's body and penetrate the cuticula. Therefore, even if M. subdolum is able to infect $C$. carinata and metacercariae have been found inside it (Reimer, 1963; Schulenburg \& Wägele, 1998; Schulenburg et al., 1999; Jensen et al., 2004), this isopod does not seem to be its most adequate host. The low parasite transmission observed in this experiment suggests that it may be difficult for cercariae swimming in the boundary layer to locate a host that remains hidden most of the time.

C. carinata from the yellow substratum aquaria were frequently visible on the surface during the first days. This higher activity implied a greater 
exposure to cercariae. For instance, swimming involves more intensive strokes of the pleopods, which will attract cercariae. Although no mesocercariae were found on pereopods, M. subdolum cercariae can attach to them as the isopod crawls on the surface (own observation). C. carinata's head was another susceptible body part, since it is frequently exposed above the sediment when they sense a possible prey nearby. Therefore, isopods from the yellow substratum had a higher probability to become infected than those from the brown substratum, which mostly remained hidden in their burrows. Still, tracks were found in the mornings of the last days, as an indicator of excursions during darkness. Hunting for food could explain this nocturnal activity. Although all C. carinata behaved similarly, burrowing immediately when first inserted in the containers, the higher daytime activity on the yellow substratum suggests that there were some unfavourable conditions associated with this sediment.

In the present short-term experiment, no differences could be established between controls and M. subdolum treatments regarding survival rates. Nonetheless, high infection intensities might still have some consequences for $C$. carinata, like it has been reported for the amphipod Corophium volutator (Mouritsen \& Jensen, 1997; Jensen et al., 1998; Meissner \& Bick, 1999). No metacercariae were ever found inside $C$. carinata's head and the encystment occurred only in pereon and pleon segments. So, no ganglia control mechanisms over the isopod's behaviour appear to be exerted by M. subdolum, as has been reported for Microphallus papillorobustus using Gammmarus sp. (Amphipoda) as intermediate hosts (Thomas et al., 1998; Combes, 2001). Although there is no clear explanation for the lower survival rates registered on the yellow substratum, it can be speculated that dense stock of nematodes may have contributed to it. They were found inside all dead isopods from the yellow sediment. The nematodes started always by feeding on the tissues of the posterior end of the dead isopod's body and their action made it difficult to identify cysts within those host individuals.

In conclusion, similar experiments should be carried out over a longer period, in order to identify parasite consequences for the biology and population dynamics of $C$. carinata. Although this isopod can be found naturally parasitised by
M. subdolum (Jensen et al., 2004), the current work revealed that the infection is not easily made. Still, this study proved that slight alterations of environmental conditions (such as minor differences in sediment composition) might have several implications (e.g. alterations in food resources, macroinvertebrates' behaviour), which may cause profound variations in the digenean infection patterns (e.g. cercariae shedding rates, transmission efficiency).

\section{Acknowledgments}

The FCT (Portuguese Foundation for Science and Technology) is acknowledged for the $\mathrm{PhD}$ grant to S. M. Ferreira (SFRH/BD/5392/2001) and also the Carlsberg Foundation for the support to K.T. Jensen.

\section{References}

Bamber, R. N., 1985. The autoecology of Cyathura carinata (Crustacea: Isopoda) in a cooling water discharge lagoon. Journal of the Marine Biological Association of the United Kingdom 65: 181-194.

Combes, C., 2001. Parasitism. The Ecology and Evolution of Intimate Interactions. The University of Chicago Press, Chicago.

Curtis, L. A. \& K. M. Hubbard, 1990. Trematode infections in a gastropod host misrepresented by observing shed cercariae. Journal of Experimental Marine Biology and Ecology 143: 131-137.

Deblock, S., 1980. Inventaire des trématodes larvaires parasites des mollusques Hydrobia (Prosobranchies) dés côtes de France. Parassitologia 22: 1-105.

Ferreira, S. M., M. A. Pardal, A. I. Lillebø, P. G. Cardoso \& J. C. Marques, 2004. Population dynamics of C. carinata (Isopoda) in an eutrophic temperate estuary. Estuarine, Coastal and Shelf Science (in press).

Holme, N. A. \& A. D. McIntyre, 1984. Methods for the Study of Marine Benthos, 2nd edn. Blackman Scientific Publications, Oxford.

Jensen, K. T. \& K. N. Mouritsen, 1992. Mass mortality in 2 common soft-bottom invertebrates, Hydrobia ulvae and Corophium volutator - the possible role of trematodes. Helgoländer Meeresuntersuchungen 46: 329-339.

Jensen, T., K. T. Jensen \& K. N. Mouritsen, 1998. The influence of the trematode Microphallus claviformis on two congeneric intermediate host species (Corophium): infection characteristics and host survival. Journal of Experimental Marine Biology and Ecology 227: 35-48.

Jensen K. T, S. M. Ferreira \& M. A. Pardal, 2004. Trematodes in a Cyathura carinata population from a temperate intertidal estuary: infection patterns and impact on host. Journal 
of the Marine Biological Association of the United Kingdom (in press).

Jormalainen, V., S. Merilaita \& J. Tuomi, 1994. Male choice and male-male competition in Idotea baltica (Crustacea, Isopoda). Ethology 96: 46-57.

Lafferty, K. D. \& A. K. Morris, 1995. Altered behavior of parasitized killifish increases susceptibility to predation by bird final hosts. Ecology 77(5): 1390-1397.

Lauckner, G., 1980. Diseases of Mollusca: Gastropoda. In Kinne, O. (ed.), Diseases of Marine Animals. Volume II. John Wiley \& Sons, Chichester: 311-424.

Lauckner, G., 1983. Diseases of Mollusca: Bivalvia. In Kinne, O. (ed.), Diseases of Marine Animals. Volume I. John Wiley \& Sons, Chichester: 477-962.

Mackenzie, K., 1999. Parasites as pollution indicators in marine ecosystems: a proposed early warning system. Marine Pollution Bulletin 38: 955-959.

McCarthy, H. O., S. Fitzpatrick \& S. W. B. Irwin, 2000. A transmissible trematode affects the direction and rhythm of movement in a marine gastropod. Animal Behaviour 59: $1161-1166$

Meissner, K., 2001. Infestation patterns of microphallid trematodes in Corophium volutator (Amphipoda). Journal of Sea Research 45: 141-151

Meissner, K. \& A. Bick, 1997. Population dynamics and ecoparasitological surveys of Corophium volutator in coastal waters in the bay of Mecklenburg (southern Baltic Sea). Diseases of Aquatic Organisms 29: 169-179.

Meissner, K. \& A. Bick, 1999. Mortality of Corophium volutator (Amphipoda.) caused by infestation with Maritrema subdolum (Digenea, Microphallidae) - laboratory studies. Diseases of Aquatic Organisms 35: 47-52.

Meyers, T. R., 1990. Diseases of Crustacea. In Kinne, O. (ed.), Diseases of Marine Animals. Volume III. John Wiley \& Sons, Chichester: 350-389.

Morley, N. J., S. W. B. Irwin \& J. M. Lewis, 2003. Pollution toxicity to the transmission of larval digeneans through their molluscan hosts. Parasitology 126: 5-26.

Mouritsen, K. N., 2001. Hitch-hiking parasite: a dark horse may be the real rider. International Journal for Parasitology 31: $1417-1420$.

Mouritsen, K. N., 2002. The Hydrobia ulvae - Maritrema subdolum association: influence of temperature, salinity, light, water pressure and secondary host exudates on cercarial emergence and longevity. Journal of Helminthology 76: 341347.

Mouritsen, K. N. \& K. T. Jensen, 1997. Parasite transmission between soft-bottom invertebrates: temperature mediated infection rates and mortality in Corophium volutator. Marine Ecology Progress Series 151: 123-134.
Mouritsen, K. N., T. Jensen \& K. T. Jensen, 1997. Parasites on an intertidal Corophium-bed: factors determining the phenology of microphallid trematodes in the intermediate host populations of the mud-snail Hydrobia ulvae and the amphipod Corophium volutator. Hydrobiologia 335: 6170 .

Mouritsen, K. N., L. T. Mouritsen \& K. T. Jensen, 1998. Change of topography and sediment characteristics on an intertidal mud-flat following mass-mortality of the amphipod Corophium volutator. Journal of the Marine Biological Association of the United Kingdom 78: 1167-1180.

Ólafsson, E. B. \& L.-E. Persson, 1986. Distribution, life cycle and demography in a brackish water population of the isopod Cyathura carinata (Kröyer) (Crustacea). Estuarine, Coastal and Shelf Science 23: 673-687.

Pardal, M.A., J. C. Marques, S. Ferreira, I. Martins, A \& I. Lillebø, 2002. Life cycle, biology and production of an estuarine Isopod (Cyathura carinata). In Pardal, M. A., J. C. Marques \& M. A. Augusto (eds), Aquatic ecology of the Mondego River basin. Global importance of local experience. Imprensa da Universidade de Coimbra: 417-434.

Reimer, L., 1963. Zur verbreitung der adulti und larvenstadien der familie Microphallidae Viana, 1924, (Trematoda, Digenea) in der Mittleren Ostsee. Zeitschrift für Parasitenkunde 23: $253-273$.

Schulenburg, J. H. G. \& J.-W. Wägele, 1998. Molecular characterisation of digenetic trematodes associated with Cyathura carinata (Crustacea: Isopoda) with a note on the utility of $18 \mathrm{~S}$ ribosomal DNA for phylogenetic analysis in the Digenea (Platyhelminthes: Trematoda). International Journal for Parasitology 28: 1425-1428.

Schulenburg, J. H. G., U. Englisch \& J.-W. Wägele, 1999. Evolution of ITS1 in the Digenea (Platyhelminthes: Trematoda). $3^{\prime}$ end sequence conservation and its philogenetic utility. Journal of Molecular Evolution 48: 2-12.

Théron, A. \& H. Moné, 1984. Chronological aspects of the host-parasite relationships between Biomphalaria glabrata and Schistosoma mansoni: cercarial production and infectivity, and growth kinetics of the host. Journal of Invertebrate Pathology 44: 209-213.

Thomas, F., F. Renaud, T. de Meeûs \& R. Poulin, 1998. Manipulation of host behaviour by parasites: ecosystem engineering in the intertidal zone? Proceedings of the Royal Society of London, Series B 265: 1091-1096.

Wägele, J.-W., 1981. Fine structure and function of the digestive tract of Cyathura carinata (Krøyer) (Crustacea, Isopoda). Zoomorphology 98: 69-88.

Zar, J. H., 1996. Biostatistical Analysis, 3rd edn. Prentice Hall International, London. 